\title{
Evaluation of Adenium obesum for Potted Ornamentals under Soilless Growing System
}

\author{
Alka Singh", A.J. Bhandari, Sachin Chavan, N.B. Patel, A.I. Patel and B.N. Patel \\ Department of Floriculture and Landscape Architecture, ASPEE College of Horticulture and \\ Forestry, Navsari Agricultural University, Navsari - 396450, Gujarat, India \\ *Corresponding author
}

\begin{tabular}{|l|}
\hline Ke y w or d s \\
Adenium, Pot plant, \\
Genotype, Varietal \\
assessment, Media. \\
\hline Article Info \\
\hline Accepted: \\
17 October 2017 \\
Available Online: \\
10 December 2017 \\
\hline
\end{tabular}

\section{A B S T R A C T}

Adenium is one of the popular flowering pot plant, with great relevance in the ornamental market due to its sculptural aspect, resistance to drought stress along with very showy flowers. A varietal evaluation of Adenium obesum was conducted with 11 different genotypes to evaluate their performance as potted ornamental plant under soilless culture. Experiment was conducted with three replications in Completely Randomized Design during the year 2015-16 and 2016-17 at the Advanced Technology Centre of Soilless system for various crops, ACHF, NAU, Navsari. The growing media consisted of mixture of cocopeat, cocofibre and Styrofoam (6:2:1). Plant growing habit and flowering attributes are important parameters for ornamental pot plant value. Plant height was observed minimum in Taiwan Dwarf $(33.90 \mathrm{~cm}$ and $33.58 \mathrm{~cm})$, followed by Mor lok Doc while Local variety showed maximum plant height $(78.54 \mathrm{~cm}$ and $75.65 \mathrm{~cm})$. Maximum number of branches per plant was recorded in Taiwan Dwarf (8.20 and 8.69) that was at par with Mor Lok Dok and Vithoons White in both the years i.e. 2015-16 and 2016-17. Maximum caudex diameter at the time of flowering was observed in Mor Lok Doc $(40.32 \mathrm{~cm}$ and $42.58 \mathrm{~cm}$ ) followed by Taiwan Dwarf variety in both the years. The leaf area was measured highest in Arrogant $\left(26.13 \mathrm{~cm}^{2}\right.$ and $\left.25.90 \mathrm{~cm}^{2}\right)$ which was at par with Deang Udam Sap whereas the lowest leaf area was measured in Picottee in both the years. Var. Deang Udam Sap showed significantly superior red flowers with maximum diameter $(9.15 \mathrm{~cm}$ and $9.1 \mathrm{~cm})$ which was on the same bar with pink coloured variety of Harry Potter. Further, diameter of corolla tube was also maximum in Deang Udam Sap $(2.32 \mathrm{~cm}$ and $2.35 \mathrm{~cm})$, followed by Arrogant in both the years. Length of corolla tube was also maximum in Deang Udam Sap $(4.01 \mathrm{~cm}$ and $4.14 \mathrm{~cm})$ and Arrogant followed by Vithoons White during both the years. Maximum flower weight was observed in variety Deang Udam Sap (2.62g and $2.44 \mathrm{~g}$ ), followed by Double Sweet Heart. Number of petals was 5 in all varieties except in Double Sweet Heart which looked showy with dual whorl having ten petals. The variety Deang Udam Sap recorded significantly highest flowers per cluster (14.10 and 14.23) as well as clusters per plant (12.13 and 12.64) that was followed by Double Sweet Heart and Harry Porter during both the years. In situ flower longevity was observed maximum in Deang Udam Sap (11.67days and 11.45days) and Double Sweet Heart (11.47days and 11.854days), followed by Arrogant and Harry Porter.

\section{Introduction}

Adenium obesum (Forssk.) Roem. \& Schult, commonly referred to as desert rose, is a relatively new flowering plant in the ornamental plant industry (McBride et al., 
2014) and gaining great popularity (Paul et al., 2015). Desert rose is a member of the dogbane family, Apocynaceae, and is native to Africa, south of the Sahara from Senegal to Sudan and Kenya, and through Saudi Arabia, Oman, and Yemen (Plaizier, 1980, Dimmit and Hanson (1991) and is widely cultivated as ornamental plant in many humid, tropical countries such as India, Philippines and Thailand with great relevance in the ornamental market (Vesiani et al., 2014).

As a result of its wide range of flower color among cultivars, attractive sculptural caudex and roots, and drought tolerance, desert rose has been increasingly produced as flowering potted plants and as landscape plants in tropical and subtropical regions (Dimmitt et al., 2009, Wannakrairoj et al., 2008; Versiani et al., 2014). Compact growth habit, thick trunk like structure with showy caudex, good branching and flowering with high level of divergence for flower colour makes adenium a desirable pot plant to display in balconies, in verandas as well as is excellent plant for xeriscaping and roof top gardens (Chavan et al., 2016, Colombo et. al., 2016).

When different cultivars are grown under identical conditions, it is the genetic factor that expresses the morphological differences. Hence selection of variety is an important criterion for successful cultivation of any ornamental plant. Varieties in adenium having variation in flower colour, petal doubleness, flowering duration, compactness in branching habit, dwarf habit, etc. are being reported (Dimmit, 1998). The local variety in adenium is having light pink flowers with reddish border in petals, showy thick light green caudex and average branching habit. Some hybrids in adenium are gaining high popularity as they bear profuse flowering and have compact growth. However, their performance with respect to growth, yield and quality cut flowers has yet not been evaluated.
Hence, the present investigation was carried out with eleven genotypes involving systematic investigation to evaluate suitable varieties for pot culture.

\section{Materials and Methods}

The present investigation was conducted at Greenhouse Complex, ASPEE College of Horticulture and Forestry, Navsari Agricultural University, Navsari (Gujarat) during the rabi season of year 2015 and 2016. Eleven genotypes of grafted adenium hybrids viz., $\mathrm{T}_{1}$ - Sudarshan (pink), $\mathrm{T}_{2}$ - Arrogant (red), $\mathrm{T}_{3^{-}}$Mung Siam (pinkish red), $\mathrm{T}_{4^{-}}$Harry Potter (pink), $\mathrm{T}_{5^{-}}$Mor Lok Dok (white), $\mathrm{T}_{6^{-}}$ Picottee, $\mathrm{T}_{7-}$ Taiwan Dwarf, $\mathrm{T}_{8}$-Deang Udam Sap (red), $\mathrm{T}_{9-}$-Double Sweet Heart (pink), $\mathrm{T}_{10^{-}}$ Vithoons White, and the $\mathrm{T}_{11}$-Local Pink variety as Check were planted a year before in 2014 before the commencement of the present study. One year old adenium hybrids of these genotypes were procured from Tropica Nursery, Mumbai and planted in Pot of $45 \mathrm{~cm}$ height, $60 \mathrm{~cm}$ width and $30 \mathrm{~cm}$ pathway at a spacing of $30 \mathrm{~cm} \times 30 \mathrm{~cm}$ in double row zigzag system in completely randomized design system with three repetitions.

The recommended package of practices was followed for raising the crop. Five plants from eleven genotypes were selected randomly and were tagged for recording the observations, during the two years. The average was worked out and results were used to evaluate the performance of different varieties on various vegetative growth and flowering characters as per genotypes.

\section{Results and Discussion}

\section{Vegetative characters}

The response of different adenium varieties under the study of growth attributes viz., plant height, number of branches and Caudex 
diameter at the time of flowering as well as leaf area, varied with each other (Table 1). Maximum plant height $(78.54 \mathrm{~cm}$ and 75.65 $\mathrm{cm})$ was observed in Local variety which was followed by Arrogant $(63.90 \mathrm{~cm}$ and 62.66 $\mathrm{cm})$ while maximum number of branches per plant (8.20 and 8.69) were recorded in Taiwan Dwarf that was at par with Mor Lok Dok and Vithoons White in both the years i.e. 2015-16 and 2016-17 (Table 1). Maximum caudex diameter $(40.32 \mathrm{~cm}$ and $42.58 \mathrm{~cm})$ at the time of flowering was observed in Mor Lok Doc and it was followed by Taiwan Dwarf variety in both the years i.e. 2015-16 and 2016-17.

Leaf production of any crop decides the spread of plant; leaves are the prime important functional units for photosynthesis, transpiration, respiration which greatly influence the growth and flower yield. The leaf area was measured highest $\left(26.13 \mathrm{~cm}^{2}\right.$ and $25.90 \mathrm{~cm}^{2}$ ) in Arrogant which was statistically at par with Deang Udam Sap $\left(25.86 \mathrm{~cm}^{2}\right.$ and $\left.25.40 \mathrm{~cm}^{2}\right)$ whereas the lowest leaf area $\left(15.77\right.$ and $\left.16.18 \mathrm{~cm}^{2}\right)$ was measured in Picottee in both the years i.e. 2015-16 and 2016-17. The difference found in the plant height, number of branches, caudex diameter and leaf area in different varieties can be due to the plant genotypes demonstrating variability for this trait.

These results clearly indicated genetic inheritance and influence of the variety with respect to growth parameters. Thus, variation among cultivars can be attributed to differences in genetic makeup and its constituents. These kinds of results are in agreement with Dimmit (1998) and Varella et al., (2015) for Adenium.

Table.1 Performance of different varieties in Adenium with regard to vegetative parameters

\begin{tabular}{|c|c|c|c|c|c|c|c|c|c|}
\hline \multirow[t]{2}{*}{$\begin{array}{l}\text { Sr. } \\
\text { No. }\end{array}$} & \multirow[t]{2}{*}{$\begin{array}{l}\text { Treatments/V } \\
\text { arieties }\end{array}$} & \multicolumn{2}{|c|}{$\begin{array}{l}\text { Plant height at } \\
\text { the time of } \\
\text { flowering }(\mathrm{cm})\end{array}$} & \multicolumn{2}{|c|}{$\begin{array}{l}\text { Caudex diameter } \\
\text { at the time of } \\
\text { flowering }(\mathrm{cm})\end{array}$} & \multicolumn{2}{|c|}{$\begin{array}{l}\text { No of branches } \\
\text { at the time of } \\
\text { flowering }\end{array}$} & \multicolumn{2}{|c|}{ Leaf $\operatorname{area}\left(\mathrm{cm}^{2}\right)$} \\
\hline & & $\begin{array}{l}2015- \\
16\end{array}$ & $\begin{array}{l}2016- \\
17\end{array}$ & $\begin{array}{l}2015- \\
16\end{array}$ & 2016-17 & $\begin{array}{l}2015- \\
16\end{array}$ & $\begin{array}{l}2016- \\
17\end{array}$ & 2015-16 & $\begin{array}{l}2016- \\
17\end{array}$ \\
\hline 1 & T1 Sudarshan & 57.17 & 61.56 & 24.07 & 26.20 & 5.67 & 5.96 & 18.18 & 18.33 \\
\hline 2 & T2 Arrogant & 63.90 & 63.90 & 23.03 & 25.20 & 5.67 & 6.37 & 26.13 & 25.90 \\
\hline 3 & T3 Mung Siam & 45.17 & 45.02 & 23.72 & 25.57 & 6.93 & 7.32 & 23.07 & 22.81 \\
\hline 4 & $\begin{array}{l}\text { T4 } \\
\text { Harry Potter }\end{array}$ & 50.03 & 52.26 & 23.61 & 26.15 & 6.47 & 6.81 & 20.43 & 20.86 \\
\hline 5 & $\begin{array}{l}\text { T5 Mor Lok } \\
\text { Dok }\end{array}$ & 41.50 & 42.84 & 40.32 & 42.58 & 7.93 & 8.36 & 18.87 & 19.21 \\
\hline 6 & T6 Picottee & 50.30 & 50.96 & 27.13 & 29.16 & 7.17 & 7.51 & 15.77 & 16.18 \\
\hline 7 & $\begin{array}{l}\text { T7 Taiwan } \\
\text { Dwarf }\end{array}$ & 33.90 & 33.58 & 34.84 & 36.42 & 8.2 & 8.69 & 19.46 & 19.73 \\
\hline 8 & $\begin{array}{l}\text { T8 Deang } \\
\text { Udam Sap }\end{array}$ & 61.13 & 61.35 & 24.95 & 27.20 & 6.17 & 6.75 & 25.86 & 25.40 \\
\hline 9 & $\begin{array}{l}\text { T9 Double } \\
\text { Sweet Heart }\end{array}$ & 55.95 & 56.88 & 27.85 & 29.51 & 7.47 & 7.88 & 22.52 & 23.36 \\
\hline 10 & $\begin{array}{l}\text { T10 Vithoons } \\
\text { White }\end{array}$ & 53.60 & 52.88 & 24.65 & 25.82 & 7.77 & 8.40 & 20.51 & 20.87 \\
\hline 11 & $\begin{array}{l}\text { T11 } \\
\text { Local var. }\end{array}$ & 78.54 & 75.65 & 25.77 & 27.41 & 5.23 & 5.71 & 16.90 & 17.13 \\
\hline & S.Em & 1.16 & 0.975 & 0.959 & 0.912 & 0.243 & 0.278 & 0.465 & 0.437 \\
\hline & C.D.(0.05) & 3.41 & 2.86 & 2.81 & 2.67 & 071 & 0.82 & 1.36 & 1.28 \\
\hline & CV\% & 3.74 & 3.11 & 6.09 & 5.40 & 6.21 & 6.64 & 3.88 & 3.62 \\
\hline
\end{tabular}


Table.2 Variation in flowering parameters in different varieties of Adenium

\begin{tabular}{|c|c|c|c|c|c|c|c|c|}
\hline \multirow[t]{2}{*}{$\begin{array}{l}\text { Sr. } \\
\text { No. }\end{array}$} & \multirow[t]{2}{*}{$\begin{array}{c}\text { Treatments/ } \\
\text { Varieties }\end{array}$} & \multicolumn{2}{|c|}{$\begin{array}{l}\text { Flower diameter } \\
(\mathrm{cm})\end{array}$} & \multirow[t]{2}{*}{$\begin{array}{c}\text { Colour of } \\
\text { Flower }\end{array}$} & \multicolumn{2}{|c|}{$\begin{array}{l}\text { length of corolla } \\
\text { tube }(\mathrm{cm})\end{array}$} & \multicolumn{2}{|c|}{$\begin{array}{c}\text { Diameter of } \\
\text { corolla tube }(\mathrm{cm})\end{array}$} \\
\hline & & $2015-16$ & $\begin{array}{l}2016- \\
17\end{array}$ & & $\begin{array}{l}2015- \\
16\end{array}$ & $\begin{array}{l}2016- \\
17\end{array}$ & $\begin{array}{l}2015- \\
16\end{array}$ & $\begin{array}{l}2016- \\
17\end{array}$ \\
\hline 1 & T1 Sudarshan & 6.11 & 6.2 & Dark Pink & 3.23 & 3.30 & 1.41 & 1.36 \\
\hline 2 & T2 Arrogant & 8.10 & 8.0 & Red & 3.99 & 4.16 & 1.87 & 1.86 \\
\hline 3 & T3 Mung Siam & 6.17 & 6.1 & Purple & 3.37 & 3.40 & 1.69 & 1.72 \\
\hline 4 & T4 Harry Potter & 8.13 & 8.2 & Pink & 3.52 & 3.54 & 1.83 & 1.73 \\
\hline 5 & $\begin{array}{l}\text { T5 Mor Lok } \\
\text { Dok }\end{array}$ & 7.07 & 7.2 & White & 3.41 & 3.50 & 1.68 & 1.68 \\
\hline 6 & T6 Picottee & 7.07 & 7.1 & Pink & 3.31 & 3.41 & 1.53 & 1.56 \\
\hline 7 & $\begin{array}{ll}\text { T7 } & \text { Taiwan } \\
\text { Dwarf } & \\
\end{array}$ & 5.26 & 5.3 & Pink & 2.43 & 2.75 & 1.47 & 1.58 \\
\hline 8 & $\begin{array}{l}\text { T8 Deang } \\
\text { Udam Sap }\end{array}$ & 9.15 & 9.1 & Dark Red & 4.01 & 4.14 & 2.32 & 2.35 \\
\hline 9 & $\begin{array}{l}\text { T9 Double } \\
\text { Sweet Heart }\end{array}$ & 7.15 & 7.2 & Pink & 3.65 & 3.69 & 1.47 & 1.60 \\
\hline 10 & $\begin{array}{l}\text { T10 Vithoons } \\
\text { White }\end{array}$ & 7.16 & 7.3 & White & 3.67 & 3.78 & 1.49 & 1.59 \\
\hline 11 & T11 Local var. & 6.15 & 6.3 & Pink & 2.77 & 2.94 & 1.35 & 1.51 \\
\hline & S.Em & 0.149 & 0.173 & & 0.083 & 0.099 & 0.034 & 0.088 \\
\hline & C.D.(0.05) & 0.44 & 0.51 & & 0.24 & 0.29 & 0.10 & 0.26 \\
\hline & CV\% & 3.66 & 4.22 & & 4.23 & 4.86 & 3.62 & 8.99 \\
\hline
\end{tabular}

Table.3 Variation in flower quality parameters in different varieties of Adenium

\begin{tabular}{|c|c|c|c|c|c|c|c|c|c|c|}
\hline \multirow[t]{2}{*}{$\begin{array}{l}\text { Sr. } \\
\text { No. }\end{array}$} & \multirow[t]{2}{*}{$\begin{array}{l}\text { Treatments } \\
\text { /Varieties }\end{array}$} & \multirow[t]{2}{*}{$\begin{array}{c}\begin{array}{c}\text { No. of petals } \\
\text { per flower }\end{array} \\
\end{array}$} & \multicolumn{2}{|c|}{$\begin{array}{c}\text { In situ longevity } \\
\text { of flower(days) }\end{array}$} & \multicolumn{2}{|c|}{$\begin{array}{l}\text { No. of flowers } \\
\text { per cluster }\end{array}$} & \multicolumn{2}{|c|}{$\begin{array}{c}\text { Flower } \\
\text { weight(g) }\end{array}$} & \multicolumn{2}{|c|}{$\begin{array}{c}\text { No of flower } \\
\text { clusters / plant }\end{array}$} \\
\hline & & & $\begin{array}{l}2015- \\
16\end{array}$ & 2016-17 & $\begin{array}{l}2015- \\
16\end{array}$ & $\begin{array}{l}2016- \\
17\end{array}$ & $\begin{array}{l}2015- \\
16\end{array}$ & $\begin{array}{l}2016- \\
17\end{array}$ & $\begin{array}{l}2015- \\
16\end{array}$ & $\begin{array}{l}2016- \\
17\end{array}$ \\
\hline 1 & T1 Sudarshan & 5 & 7.87 & 7.70 & 5.67 & 5.98 & 0.87 & 0.89 & 5.97 & 5.88 \\
\hline 2 & T2 Arrogant & 5 & 10.53 & 10.60 & 7.07 & 7.20 & 1.32 & 1.27 & 6.10 & 6.04 \\
\hline 3 & T3 Mung Siam & 5 & 8.20 & 8.62 & 4.50 & 4.33 & 0.77 & 0.73 & 5.47 & 5.59 \\
\hline 4 & T4 Harry Potter & 5 & 9.53 & 9.53 & 11.03 & 11.20 & 1.61 & 1.54 & 9.13 & 9.18 \\
\hline 5 & T5 Mor Lok Dok & 5 & 8.93 & 9.04 & 9.13 & 9.22 & 0.79 & 0.82 & 12.47 & 12.65 \\
\hline 6 & T6 Picottee & 5 & 9.73 & 9.59 & 8.23 & 8.33 & 0.71 & 0.75 & 7.83 & 7.95 \\
\hline 7 & T7 Taiwan Dwarf & 5 & 9.47 & 9.66 & 4.20 & 4.13 & 0.52 & 0.59 & 4.40 & 4.49 \\
\hline 8 & T8 Deang Udam Sap & 5 & 11.67 & 11.45 & 14.10 & 14.23 & 2.62 & 2.44 & 12.13 & 12.64 \\
\hline 9 & $\begin{array}{l}\text { T9 Double Sweet } \\
\text { Heart }\end{array}$ & 10 & 11.47 & 11.84 & 8.27 & 8.38 & 1.79 & 1.84 & 11.13 & 11.24 \\
\hline 10 & T10 Vithoons White & 5 & 8.13 & 8.41 & 6.80 & 6.91 & 1.38 & 1.52 & 6.87 & 7.23 \\
\hline 11 & T11 Local var. & 5 & 6.83 & 6.52 & 4.07 & 4.26 & 0.90 & 0.90 & 4.03 & 4.23 \\
\hline & S.Em & & 0.258 & 0.308 & 0.146 & 0.15 & 0.034 & 0.056 & 0.151 & 0.131 \\
\hline & C.D.(0.05) & & 0.76 & 0.90 & 0.43 & 0.44 & 0.10 & 0.16 & 0.44 & 0.38 \\
\hline & CV\% & & 4.80 & 5.69 & 3.34 & 3.39 & 4.90 & 7.98 & 3.35 & 2.85 \\
\hline
\end{tabular}




\section{Flower parameters}

Flower colour and flower size are important parameters to determine ornamental pot plant value. Flower size parameter viz., flower diameter, length of corolla tube and diameter of corolla tube significantly differed in different varieties (Table 2). The flowers of red colour variety Deang Udam Sap showed significantly superior flower diameter $(9.15 \mathrm{~cm}$ and $9.10 \mathrm{~cm})$ which was on the same bar with pink coloured variety of Harry Potter $(8.13 \mathrm{~cm}$ and $8.20 \mathrm{~cm})$. Further, diameter of corolla tube $(2.32 \mathrm{~cm}$ and $2.35 \mathrm{~cm}$ ) was maximum in Deang Udam Sap, followed by Arrogant in both the years i.e. 2015-16 and 2016-17. Length of corolla tube was also maximum in Deang Udam Sap (4.01 $\mathrm{cm}$ and $4.14 \mathrm{~cm})$ and Arrogant $(3.99 \mathrm{~cm}$ and $4.16 \mathrm{~cm}$ ) followed by variety Vithoons White during both the years.

Further, Flower weight and number of petals are also important parameters for flower pot plant. Maximum flower weight $(2.62 \mathrm{~g}$ and $2.44 \mathrm{~g}$ ) was observed in variety Deang Udam Sap, followed by Double Sweet Heart during both the years. No of petals were 5 in all varieties except in Double Sweet Heart which looked showy with dual whorl having ten petals (Table 3).

Number of flowers, flower clusters and in-situ flower longevity ultimately decide the ornamental pot plant value and influence by consumer's preference. The variety Deang Udam Sap recorded significantly maximum flowers per cluster (14.10 and 14.23) as well as flower clusters per plant (12.13 and 12.64) followed by Double Sweet Heart and Harry Porter in both the year i.e. 2015-16 and 2016-17 (Table 3).

Genetic constituents of the variety along with the management factor and environmental conditions govern the plant growth. It is the genetic factor that expresses their morphological differences when different cultivars are grown under identical conditions under same management.
In situ flower longevity was observed maximum in Deang Udam Sap (11.67 days) and Double Sweet Heart (11.47 days), followed by Arrogant (10.53 days) and Harry Porter (9.53 days). Enhanced insitu longevity may be ascribed to good vegetative growth and flowering in these varieties especially Deang Udam Sap having the highest flower clusters per plant.

Variation in different floral characters might be owing to the divergence in these genotypes or wide range in nature of growth as also suggested by da Silva (2015). Earlier work with regard to varietal evaluation in Adenium is almost negligible.

However, difference in branching habit, flower size, flower clusters per plant in different varieties have been earlier reported in various ornamental pot plants like chrysanthemum (Mohapatra et al., 2000, Madhu Bala 2015), rose (Shahrin et al., 2015,) and Orchids (Sugapriya et al., 2012).

Genetic factor express the morphological difference when different varieties are grown under identical conditions. The selection of a cultivar for a particular region is of much significance as it shows considerable variability in several characters, when grown under a particular environment.

The per se performance of genotypes Deang Udam Sap (red), Double Sweet Heart (pink and double) and Harry Porter (pink with reddish shade) are best suited for South Gujarat conditions, since they perform better than other varieties with respect to the desirable characters like number of flowers per cluster, flower size, flower clusters per plant, leaf area, insitu flower longevity, etc. Further, Taiwan Dwarf is also interesting genotype with regard to dwarf plant height, higher branching with moderate flowering that can be preferred as natural bonsai. The aim of the screening of adenium varieties was to evaluate those varieties which exhibit novel and commercially valuable characteristics. Thus, the results will be useful for farmers as diversified crop for pot culture, 
nurserymen and breeders to improve ornamental pot plant quality in adenium.

\section{References}

Chavan S., Singh, A, Bhandari A. J. and Patel B.N. (2016) Management of Potted Adeniums. Floriculture Today, 21(2), 10:13.

Colombo, R.C., Favetta, V., de Melo T. D., de Faria, R. T., de Aguiar e Silva, M. A., 2016. Potting media, growth and build-up of nutrients in container-grown desert rose. Australian Journal of Crop Science, 10(2), 258-263.

Dimmit M and Hanson C (1991). The genus Adenium in cultivation. Part 1: A. obesum and A. multiflorum. Cactus and Succulent Journal; 63(5), 223-225.

Dimmitt, M.G. 1998. Adenium culture, growing large specimens quickly. Cactus Succulent J. 20, 59-64.

Dimmitt, M.G., G. Joseph, and D. Palzkill. 2009. Adenium: Sculptural elegance, floral extravagance. Scathingly Brilliant Idea, Tucson, AZ.

Madhu Bala 2015. Evaluation of Chrysanthemum (Chrysanthemum morifolium Ramat.) Genotypes for Morphological Traits, Journal of Horticulture Science, 10(2), 242-244.

McBride, K. M., Henny, R. J., Mellich, T. A. and Chen J. 2014. Mineral Nutrition of Adenium obesum 'Red' Hortscience 49(12), 1518-1522.

Mohapatra Anuradha, Arora, J. S. and Sidhu, G. S. 2000. Evaluation of chrysanthemum varieties for pot culture. Journal of Ornamental Horticulture (New Series), 3(2), 79-82.
Paul, D., Biswas, K. and Sinha, S. K. 2015. Biological Activities of Adenium obesum (Forssk.) Roem. \& Schult.: A Concise Review. Malaya Journal of Biosciences, 2(4), 214-220.

Plaizier, A.C. 1980. A revision of Adenium Roem. and Schult. and of Diplorhynchus Welw. Ex Fic. and Hiern (Apocynaceae). Mededelingen Landbouwhogeschool, 80, $1-40$.

Shahrin, S., Roni, M. Z. K., Taufique, T., Mehraj, H. and Jamal Uddin, A. F. M. (2015). Study on flowering characteristics and categorization of rose cultivars for color, fragrance and usage. Journal of Bioscience and Agriculture Research 04(01): 20-30.

Sugapriya, S., Mathad, J.C., Patil, A. A., Hegde, R.V., Lingaraju, S. and Biradar M. S. 2012. Evaluation of Dendrobium orchids for growth and yield grown under greenhouse. Karnataka J. Agric. Sci.,25 (1), 104-107.

Varella,T.L., da Silva, G.M., Maximiliano K. Z., Mikovski, A. I., da Silva Nunes, J.R., De Carvalho, I.F. and da Silva, M L. 2015. In vitro germination of desert rose varieties. Ornamental Horticulture 21(2), 227-234.

Versiani, M.A., Ahmeda, S. K.., Ikrama, A., Alia, S.T., Yasmeena, K., Faizib, S. 2014. Chemical Constituents and Biological Activities of Adenium obesum (Forsk.) Roem. et Schult. Chemistry \& Biodiversity, Zurich, 11 (6), 171-180.

Wannakrairoj, S. 2008. Status of ornamental plant in Thailand. Acta Horticulturae, 788, 29-36.

\section{How to cite this article:}

Alka Singh, A.J. Bhandari, Sachin Chavan, N.B. Patel, A.I. Patel and Patel, B.N. 2017. Evaluation of Adenium obesum for Potted Ornamentals under Soilless Growing System. Int.J.Curr.Microbiol.App.Sci. 6(12): 2141-2146. doi: https://doi.org/10.20546/ijcmas.2017.612.246 